\title{
Når hjemme er mere end et sted \\ Møder med Danmark blandt somaliere i diaspora
}

Af Nauja Kleist

Hjem og tilborsforbold fair en serlig betydning $i$ diaspora. En somalisk kvindes og mands italesettelser af livet $i$ Danmark viser, boordan moderne med velferdssamfundet er med til at skabe forskellige fortellinger om 'somalisk kultur', hvor køn står $i$ centrum.

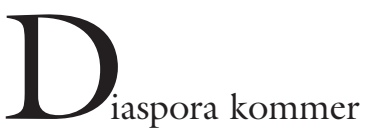
af de græske ord speiro og dia: at så over (Cohen 1997, ix). Begrebet henviser til en befolkningsgruppes spredning væk fra oprindelseslandet over lang tid, hvor den jødiske diaspora danner udgangspunkt for forståelsen. I de senere år er begrebet imidlertid udvidet til at omfatte andre befolkningsgrupper, præget af en fælles bevidsthed om og måske længsel efter hjemlandet, som kan være forestillet, fortidigt eller reelt eksisterende. Eller med henvisning til såningsmetaforen: Grupper med stærke forestillinger om at have rødder et andet sted, end i opholdslandet.

I denne artikel analyserer jeg, hvordan italesættelser af hjem og tilhørsforhold blandt somaliere i diaspora er relationelle begreber, der blandt andet skabes i mødet med Danmark. Mit udgangspunkt er en række samtaler om tilhørsforhold, hverdagsliv i Danmark, erindringer om tiden i Somalia og fremtidsdrømme med en gruppe somaliske kvinder og mænd bosat i 
København og omegn. ${ }^{1}$ Ud af disse samtaler har jeg valgt forst og fremmest at fokusere på to personer, her kaldt Liza og Omar. Lizas og Omars to narrativer står i centrum for artiklen, da de i høj grad kredser om køn som et centralt element i italesættelserne af hjem, tilhørsforhold og marginalisering. Hvor de interviewede somalieres historier er mangfoldige og indeholder forskellige oplevelser og vurderinger af livet i Danmark, er det fælles, at de taler om Somalia som hjemland, og at deres familier er spredt ud over flere forskellige lande og $\mathrm{i}$ flere verdensdele. De er med andre ord en del af den somaliske diaspora.

\section{DEN SOMALISKE DIASPORA}

De godt 14.500 somaliere (Udlændingestyrelsen 2000) er blandt de større grupper af udenlandske statsborgere i Danmark. Langt størstedelen er kommet til landet som flygtninge eller familiesammenforte i 1990'erne, da borgerkrig, anarki og humanitære katastrofer brød ud i hele Somalia. ${ }^{2}$ Det præcise antal somaliske flygtninge globalt set kendes ikke, men er anslået til knap $500.000 \mathrm{i}$ år 2000 (UNHCR 2000). Udover nabolandene, hvor det største antal befinder sig, er den somaliske diaspora spredt over det meste af verden, fra Finland til Sydafrika, fra Canada til Australien. Og altså også i Danmark. Hvor somalierne er en forholdsvis ny gruppe udlændinge i Danmark, har gruppen lang tradition for mobilitet - også udover det traditionelle nomadeliv, som har kendetegnet en del af somaliernes levevis i Somalia. Både under koloniseringerne fra slutningen af 1800-tallet frem til 1960 og derefter har især somaliske mænd arbejdet som blandt andet sømænd og fyrbødere, handelsfolk og soldater (Griffiths 1997, Utteh 1997, Farah 2000). Mange har også arbejdet i olieindustrien i Golfstaterne siden 1950'erne (Lewis 1994, Geschekter 1997). Somalierne har med andre ord globale migrationsmønstre, hvilket komplicerer spørgsmå- let om, hvor og hvad hjemme og hjemlandet er.

Positionen som 'somalier i Danmark' og de enkeltes historier kan naturligvis ikke samles under ét, man kan ikke tale om 'den somaliske gruppe i Danmark' som et homogent fællesskab. Alligevel har de fleste somaliere i udgangspunktet noget til fælles, nemlig at de i mødet med det danske samfund tildeles en position som somalisk flygtning. $\mathrm{Og}$ da somalierne om nogen er en gruppe, mange har meninger om, er en sådan meningstilskrivelse ikke helt uskyldig. Således har somalierne ry for at være 'meget specielle' og svære at integrere (Skak 1998). Også medierne har gjort deres til at cementere somalierne som en serlig gruppe. Gruppen stod i centrum i Ekstrabladets kampagne om de fremmede i 1997, og andre aviser fulgte efter med historier om, hvordan somaliere misbrugte det danske velfærdssystem (Jørgensen \& Bülow 1999). Ved hjælp af argumenter om somaliernes anderledeshed $\mathrm{i}$ forhold til kultur, religion, uddannelse og udseende (Fadel, Hervik \& Vestergaard 1999, Skak 1998) fremhævede medierne somaliernes ikke-tilhørsforhold til Danmark. Også på den politiske arena har somalierne fået negativ opmærksomhed, mest markant med daværende medlem af Fremskridtspartiet Tom Behnkes udtalelse om, at somalierne burde smides ud med faldskærm over Somalia. En udtalelse, som har vakt stor harme - i Danmark som i Somalia.

Hvor medierne og nogle politikere i høj grad har interesseret sig for somaliere, eksisterer der fortsat overraskende lidt videnskabelig litteratur om den somaliske diaspora i Danmark. ${ }^{3}$ At beskæftige sig med 'somaliske tilhørsforhold' er således at begive sig ind i et på en gang uopdyrket og stærkt politiseret felt. Dette har både formidlingsetiske aspekter (hvordan kan komplekse problemstillinger formidles uden at bidrage til stereotyper og andetgørelse), såvel som konsekvenser for tilhørsforholdene som sådan. Den diasporiske position er med andre ord ikke kun et spørgsmål om forbin- 
delser til hjemlandet, men handler også om relationerne til Danmark.

\section{DIASPORA, HJEM OG LOKALISERINGENS POLITIKKER}

Diasporabegrebet er især gennem de sidste ti år igen kommet på den teoretiske dagsorden $^{4}$ og anvendes nu ofte som en metaforisk fællesbetegnelse, der samler forskellige kategorier som flygtninge, indvandrere eller naturaliserede statsborgere (Cohen 1997, 21). En sådan fællesbetegnelse har den fordel at overkomme det snit, der ofte lægges mellem disse forskellige mobilitetskategorier, hvor diasporiske grupper i 'virkelighedens verden' interagerer på tværs af kategorierne (jf. Brah 1996; Crisp 1999; Fink-Nielsen \& Kleist 2000). I dette perspektiv inkluderer den somaliske diaspora både flygtninge, indvandrere, danske statsborgere af somalisk herkomst, familiesammenførte og andre, der definerer sig som somaliere.

Diasporaperspektiv søger som sagt at gribe flertydigheden i en befolkningsgruppes oplevelse af at leve væk fra et oprindeligt hjemland. Dette hjemland kan dog ikke nødvendigvis stedfæstes på et landkort eller reduceres til et bestemt sted.

"The centering of diasporas around an axis of origin and return overrides the specific locations (identifications and "dis-identifications", both constructive and defensive) necessary for the maintenance of diasporic social forms. The empowering paradox of diaspora is that dwelling here assumes a solidarity and connection there. But there is not necessarily a single place or an exclusivist nation" (Clifford 1994, 322, forfatterens fremhævelser).

Som også litteraten Rosemary M. George gør opmærksom på, er hjem og hjemland $\mathrm{i}$ lige så høj grad forestillede steder i det mentale landskab, som konkret lokaliteter (George 1996, 11). På grund af adskillelsen og distancen i både tid og rum må de diasporiske hjem leves, huskes og fortælles for at fortsætte som centrale fixpunkter i den diasporiske erindring. Hjemme er altså på sin vis noget, der ikke bare er, men aktivt gøres. Samtidig er det diasporiske hjemme kompliceret af, at familie og venner måske er spredt over store dele af kloden. For hvor er hjemlandet, hvis den nærmeste familie bor i flere forskellige lande, måske flere verdensdele?

I bogen The Politics of Home (1996) udforsker George begrebet hjem og karakteriserer overordnet begrebet som organiseret omkring spændingsfeltet inklusion og eksklusion. Som en måde at etablere forskel på og som en afgørende identitetsakse (George 1996, 2). Nogle hører til, andre gør ikke. Nogle har hjemme, andre har ikke. Hvad og hvor hjemme er, er defineret af subjektets position. Begrebet the politics of location, her oversat som lokaliseringens politikker, er et brugbart greb til at arbejde med krydsende identitetsakser og positionering (Braidotti 1994; Brah 1996). Brah definerer således lokaliseringens politik som "the simultaneous situatedness within gendered spaces of class, racism, ethnicity, sexuality, age" (Brah 1996, 204). Lokaliseringens politikker rummer altså dobbeltheden i, hvor man taler fra - den kønnede og racialiserede krop - og hvordan man positioneres i forskellige sociale og politiske rum. Både Lizas og Omars fortællinger er eksempler på dette.

\section{LIZAS HISTORIE: “.... OG SÅ PLUDSELIG BLIVER MAN EN ANDEN"}

Det var meget anderledes at komme til Danmark, end Liza havde troet, da hun som ung og nygift ankom til København i 1987 for at bo sammen med sin daværende somaliske mand. "Der var sne dengang og det var meget koldt", fortæller hun. Danmark var ikke "den flotte diamant", som hun og andre somaliere havde forestillet sig Vesten. I Somalia havde den unge ambitiøse kvinde drømt om at gå på universitetet i USA og troede, at Danmark ville være 
et skridt på vejen. Det blev en skuffelse. Lejligheden var lille og dårlig, meget mindre end familiens store lejlighed i Somalia. Året efter brød borgerkrigen ud i det nordlige Somalia og det blev umuligt for Liza at tage tilbage. Familie og venner blev spredt i Tyskland, USA, England, Somalia og Danmark. Og universitetskarrieren til et liv med ufaglært arbejde, siden arbejdsløshed og skilsmisse.

Nu bor Liza i en lille lejlighed i en forstad til København med sine fire små børn. Ensomheden er det sværeste, siger hun, altid at være ene om at løfte ansvaret for familien. "Det er rart nogle gange at mødes og snakke sammen, men her i Danmark er der altid så meget at gøre - man føler sig meget træt. Så man ses ikke så tit." Isolationen deler hun med mange andre somaliske kvinder, som savner kvindenetværk, de husker fra tiden i Somalia. Savner at få hjæelp til børne- og husarbejdet, at fă social og praktisk støtte. De oplever isolationen med det fulde ansvar for familien som vanskelig at slippe ud af, mens 'man aldrig var alene $\mathrm{i}$ Somalia'. Livet i Danmark bliver lig en hård hverdag, som mange familier går i stykker af. De disintegrerende kvindenetværk sætter den 'danske kultur' i perspektiv i forhold til erindringen om den 'somaliske måde', hvor køn, kultur og tilhørsforhold smelter sammen på en for dem ønskelig og eftertragtet måde. Som kvindefællesskab og solidaritet modsat isolation og marginalisering. Men måske mest af alt som en længsel efter et andet liv.

For som enlig mor uden uddannelse og med store familieforpligtelser er Lizas handlerum begrænset. Både i forhold til social og geografisk mobilitet. "Så pludselig bliver man en anden", som hun siger. "Som man ikke venter". Andethed slår igennem ikke bare i forhold til, hvad Liza havde forventet og håbet af sin livsvej. Men også i forhold til at indgå i en position som den Anden. Liza fortæller, hvordan hun næsten dagligt møder især ældre mennesker, der siger hun skal rejse hjem. De dag- lige oplevelser af andetgørelse og racisme er medvirkende til at skabe Danmark som et ikke-hjem. Og Liza længes væk. 'Den flotte diamant' viste sig at være mørkt, barskt, koldt og ensomt sted. Men Danmark som sted defineres ikke blot i modsxtning til Somalia, men også i forhold til andre steder, hvor det ifølge Liza og andre somaliere er muligt at leve som somalier. Liza drømmer om London:

"Det er også meget godt at bo i London. Ja. Man føler sig som i Somalia [...] Der er mange somaliere, og de lever på den somaliske måde. De har meget kontakt. De fleste mænd har arbejde, kvinderne går hjemme, som somaliske kvinder gør. Men... jeg er alene, jeg kan ikke bo derovre. Hvis man har en mand, så er det godt. Og hvis man tjener penge. Men folk får også noget, ligesom bistandshjælp. Men den er ikke så stor [...] Der er folk fra hele verden - alle mulige mennesker fra forskellige lande. Men det bedste er, at der ikke er nogen, der siger du er indvandrer, eller du kommer fra Somalia, eller du er udlænding. Der er ikke nogen, der snakker på den måde. Så hvis man bor i London, så bliver man fri”.

London er næsten som Somalia, mener Liza. Kendetegnet af 'somaliske' kønsrelationer: Mændene har arbejde, og kvinderne er hjemme sammen med børnene. Ligesom London efter hendes opfattelse er kendetegnet af fraværet af kategoriseringer som fremmed - indvandrer, somalier eller udlænding. Med begrebet lokaliseringens politikker kan vi sige, at i Lizas fortælling fremstår London som et socialt rum, hvor hendes position som sort somalisk hjemmegående kvinde umiddelbart står i en mindre marginaliseret position i forhold til de samfundsmæssige køns- og racehierarkier i Danmark. I forhold til mangfoldighed, muligheder for uddannelse og arbejde samt at være accepteret som somalier ligger multikulturelle og engelsksprogede lande som England, Canada og USA højt i hierarkiet over efterstræbelsesværdige steder - ikke 


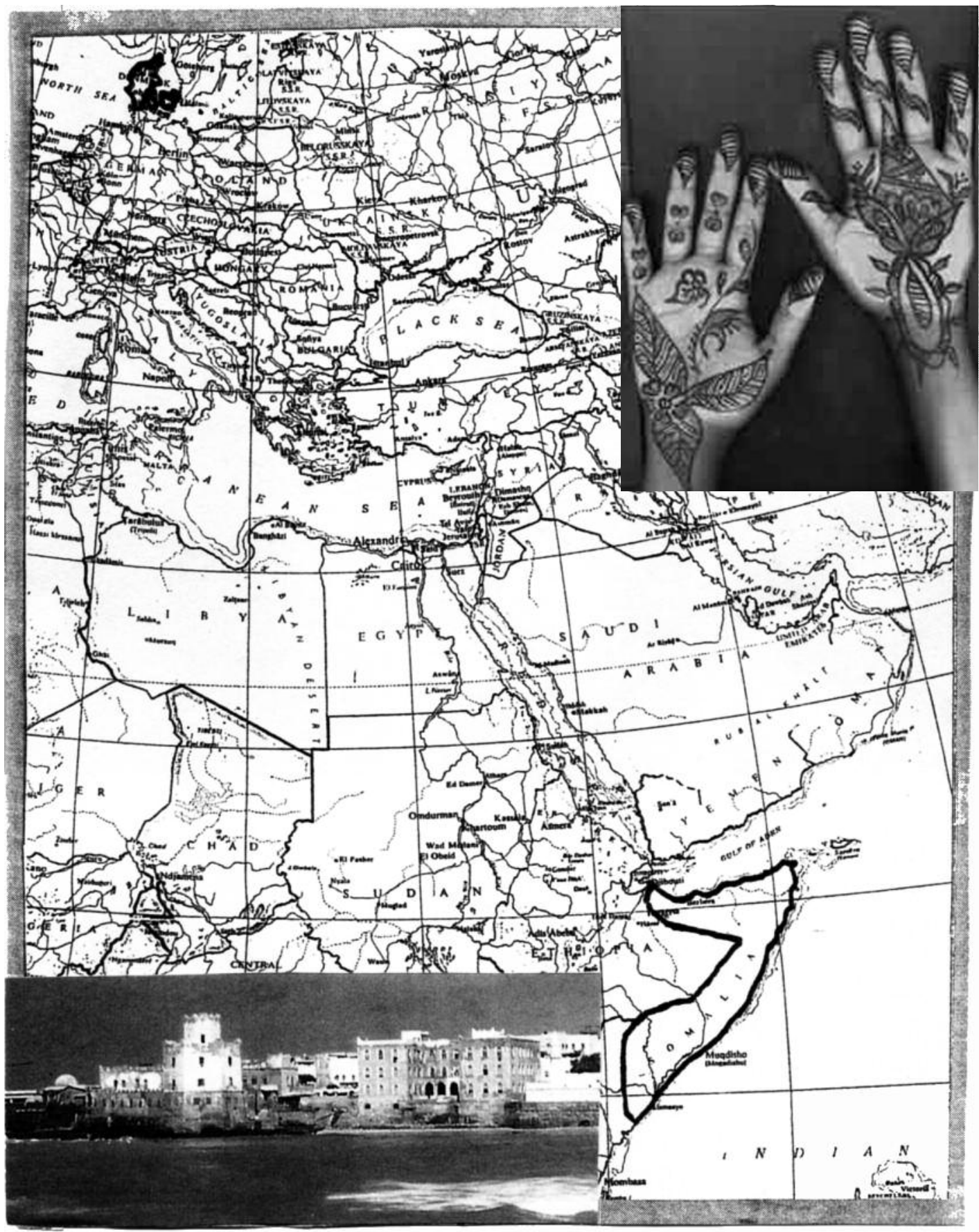

Kort med indsat foto af Mogadishu, hovedstaden i Somalia og af hennadekorerede honder, fra projektet A Sense of belonging: Somali settlement experience in Canada. 
blot for Liza, men for mange andre somaliere. Men som Liza selv siger, kan hun ikke bo der som enlig mor uden uddannelse. Det sociale system i Danmark giver bedre muligheder for økonomisk at klare hverdagslivet. Det forjættede sted udgør ikke en reel mulighed for hende grundet koblingen mellem køn, muligheder og forpligtelser.

\section{OMARS HISTORIE: TRUET MASKULINITET}

Hvor det danske velfærdssystem gør det muligt for enlige mødre som Liza at overleve med fire børn, oplever mange mænd mødet med systemet som mere truende. I somaliske fortællinger om køn og kultur er kønnenes komplementære rollefordeling ofte understreget (Wargeys 2001, nr. 22): Kvinden arbejder i hjemmet, og manden er forsørger. Som Liza taler om, når hun drømmer om London og 'den somaliske måde'. Disse idealfigurer kommer under pres i det danske samfund, hvor både mænd og kvinder arbejder eller har adgang til økonomiske velfærdsydelser. Således er det en gennemgående forklaring, både blandt somaliske mænd og kvinder, at især mændenes møde med den danske velfærdsmodel er svært. Et fænomen, som også kendes blandt somaliere $\mathrm{i}$ andre vestlige lande (Affi 1997, Griffiths 1997, Mohamed 1997, Farah 2000).

I lande med lave eller ikke-eksisterende velfærdsydelser og et mere åbent arbejdsmarked forklares mændenes pressede situation ofte med, at kvinderne har lettere adgang til lavprestige omsorgsarbejde og/eller informelt arbejde (Farah 2000). I Danmark er både somaliske mænds og kvinders erhvervsfrekvens imidlertid meget lav, ${ }^{5}$ og frustrationerne over ikke at kunne komme i arbejde, bruge sine kvalifikationer eller forfølge sine ambitioner, synes udbredte (se Fink-Nielsen, Hansen \& Kleist (forthcoming)). For nogle mænd spiller den marginaliserede position på arbejdsmarkedet og mødet med velfærdssystemet sammen med frustrationer over ændrede køns- og familierelationer. Når både kvinder og mænd făr "en lille bankbog, hvor de har deres penge stående" af kommunen, forsvinder det forsørgende mandlige familieoverhoved som mulig maskulin magtposition i især de familier, hvor manden er på overførselsindkomst. Hvilket kan skabe en følelse af, at den danske velfærdsstat truer familielivet ved at nedbryde 'somaliske' familiestrukturer og sætte kønsrelationer på spil.

Opbruddet af familierelationer bliver af nogle somaliske mænd associeret med en 'kulturkamp', hvor det danske system undertrykker den somaliske kultur. Både blandt danskere og somaliere eksisterer der stærke opfattelser af henholdsvis dansk og somalisk kultur som afgrænsede og veldefinerede størrelser, med kønnet som central markør. Som det ofte er påpeget, tillægges kvinder og mænd forskellige forventninger om handlemønstre, hvor kvindekønnet ofte forventes at kropsliggøre nationen og videreføre 'traditionen' (Yuval-Davis \& Anthias 1989, Peltman 1996, Mørck 1998). Omars historie er et eksempel på, hvordan kvindekønnet bliver en særlig betydningsfuld markør i mødet med Danmark - eller med andre ord: Hvordan kombinationen af racialisering, marginalisering og xndrede kønsrelationer støder sammen og 'truer' maskuline magtpositioner.

Omar kom til Danmark i starten af 1990'erne efter borgerkrigen for alvor brød ud i hovedstaden Mogadishu. Som ung mand læste han jura og drømte om en karriere som dommer; nu efter flugt fra borgerkrig og små ti år som arbejdsløs i Danmark er denne drøm effektivt skrinlagt. Hans mor og søskende bor fortsat i Somalia, og Omar støtter dem økonomisk, når der er noget til overs af bistandshjælpen. At tage tilbage til Somalia er ikke en mulighed; de fortsatte uroligheder, fattigdom, manglende retsvæsen, skole- og sundshedssystem gør denne drøm urealistisk. Og hvor Omar betegner velfærdsydelserne i Danmark som "meget flotte", er han vred 
over den manglende respekt og det manglende ligeværd i sin dagligdag. Vred over hvad han opfatter som utidig indblanding $\mathrm{i}$ hans familieforhold. Som at hans barn er blevet sendt til psykolog uden hans samtykke. Og risikoen for tvangsfjernelse og andre sanktioner mod familien, som han og andre somaliske forældre frygter. At staten på denne vidtgående måde kan blande sig i familieforhold og opdragelse, mens hverdagen er præget af, 'at man blander sig uden om' hinandens problemer, forvirrer mange.

For Omar er mødet mellem somaliere og danskere et spørgsmål om magt og kultur, et spørgsmål om at danskerne er mod den somaliske kultur. For ham bliver mødet med det danske velfærdssystem yderligere polariseret af, at systemet først og fremmest befolkes af kvinder. Kvindelige sagsbehandlere, som efter hans mening påvirker somaliske kvinder til at bortkaste den somaliske kultur ved for eksempel at tale mod slør eller mod Islam, og som skaber særlige rum og goder for kvinder, som måske er helt eller delvis lukkede for mænd. Dette bliver af Omar oplevet som, at staten eller kommunen går ind og skaber afstand og splid mellem ægtefællerne og i familierne:

"I den kommune, hvor jeg bor, har de et kvindeprojekt ... de har et lokale og der kommer flere damer, og der er kvinder, der taler hele tiden. Der er ingen mand. Og det er voreskvinder, og vi ved ikke, hvad det drejer sig om, og hvad de fortxller dem. Om det er en hjælp, eller om de laver undertrykkelse, eller de vil have tørklædet væk eller religion væk eller om de giver penge og siger, at du så skal lade din mand være eller sådan noget. De laver undertrykkelse og fjerner vores kultur. $\mathrm{Og}$ det de laver, kalder de integration. Men det er assimilation."

Med hjælp fra begrebet lokaliseringens politikker kan man sige, at for mænd som Omar spiller racialisering, marginalisering og konservative kønsidealer sammen til en position, hvor udelukkelsen fra det danske sam- fund bliver gensidigt opretholdt. "Du er ingenting", siger Omar om at være somalier i det danske system, og fortsætter "du er ligesom et dyr, for du har ikke en fremtid. Du er ingenting. Danmark er sådan; problemet, det er dig." Hans oplevelse af, at der ikke er plads til ham i Danmark som somalier, bliver understreget af, hvad han oplever som en yderligere marginalisering som somalisk mand. En frustration, som han forklarer, er delt af mange andre mænd, og som er medvirkende til, at mange, især unge, har problemer og laver ballade.

Det er vigtigt at understrege, at Omars eksempel er én position blandt andre; eksemplet kan ikke tages til indtægt for en generel karakteristik. Somaliske mænd er - ligesom alle andre mænd - forskellige og med forskellige måder at udleve maskuliniteten på. Dét, der til gengæld er vigtigt, er at være opmærksom på, hvordan nogle mænd kommer til at indtage en position $\mathrm{i}$ det kønnede velfærdssystem, hvor de opfatter sig selv som truede og magtesløse som somaliske mond. Og det har konsekvenser for tilhørsforholdet til Danmark.

\section{De umulige \\ BINDESTREGSIDENTITETER?}

I bogen Bindestregs-Danskere. Fortellinger om køn, generationer og etnicitet fortæller Yvonne Mørck (1998) om sit arbejde blandt etniske minoritetsunge i København med familiebaggrund i Tyrkiet, Pakistan og Marokko. Hendes konklusion er, at de unges identiteter rækker ind i både den danske og i (forældre-)hjemlandets kultur og handlemåder. Mørck postulerer ikke, at dette er smertefrit, men hævder, at de unge er både-og; at de lever et bindestregsliv.

I de interviewede somalieres tilfælde er bindestregen dog oftest fraværende. Både i somaliernes kategoriseringer af sig selv som somaliere $i$ Danmark og af gentagne oplevelser af hverdagsracisme og udgrænsninger fra danskhed og medborgerskab. Den fraværende bindestregsidentitet skyldes for- 
mentlig det tilsyneladende umulige tilhørsforhold på den ene side af bindestregen; man kan ikke være sort dansker. Følelsen af en udgrænsning fra danskheden lokaliseres gang på gang i kroppen. Kroppen fremstår som arena for kampe om tilhørsforhold den hvide versus den sorte hud - danskheden versus somaliskheden. Dette tilhørsforhold er forankret i kroppen og er uforanderligt over tid, hvorfor man nok kan blive dansk statsborger, men aldrig dansker. Man er, som en ung kvinde, siger "somalier $i$ bud". Uanset om man er dansk indeni, forbliver man fremmed udenpå. Frustrationen over gentagende demografiske fremskrivninger om antallet af såkaldte indvandrere og efterkommere fra mindre udviklede lande' er udpræget. Det er et centralt spørgsmål, om hvor lang tid det tager at blive dansker, og hvad der helt præcist skal til, hvis 'fremmedheden' sidder fast i huden. Hvornår bliver man dansker - ikke kun som statsborger, men også som en ligeværdig medborger? Fastholdes udgrænsningen i statslige politikker, statistiske beregninger og ikke mindst i hverdagslivets racisme fastholdes også frustration og gensidige fordomme. At Somalia er hjemlandet behøver ikke at betyde, at Danmark ikke er det.

For mens oplevelser af racisme hos nogle fylder meget i hverdagen, forklarer andre dem som exceptionelle eller betydningsløse. Både mænd og kvinder lægger afstand til italesættelserne af marginalisering og fremhæver, at de selv og deres omgangskreds ikke kan genkende sig selv i dette billede. De frasiger sig dermed kategoriseringen som offer, besværlig somalier, uintegrerbar eller slet og ret fremmed. Disse mennesker nærmer sig dermed bindestregsidentiteten og understreger deres aktive medborgerskab og succes i det danske samfund gennem arbejde, foreningsaktiviteter og politisk arbejde. De forstyrrer dermed det lidt entydige billede, jeg har analyseret frem i artiklen. Samtidig understreger de pointen om det diasporiske hjems flertydighed.

\section{SYMBOLSKE OG PRAKTISKE HJEM}

I min artikel har jeg vist, hvordan begreberne hjemme, hjemland og somalisk kultur italesættes som steder og fænomener, der blandt andet får mening i modsætning til oplevelser af hverdagslivets racisme og marginalisering i Danmark. Køn fremstår som et vigtigt element i definitionerne af hjemland og kultur, men det er vigtigt at lægge mærke til, at kønnets betydning og eventuelle ændringer i køns- og familierelationer skifter alt efter perspektiv og position.

I denne sammenhæng er distinktionen mellem det praktiske og symbolske hjem brugbar. Det praktiske hjem henviser til de lokaliteter, hvor livet faktisk leves; det symbolske hjem befinder sig på længslernes landkort, det være sig et erindret Somalia eller en længsel efter et sted, hvor man kan leve som somalier. Hverken for Liza eller Omar er Danmark et fuldgyldigt hjemme og køn er en vigtig faktor. For Liza muliggør det danske velfærdssystem et liv som enlig ufaglært mor og Danmark udgør dermed et praktisk hjem, karakteriseret ved marginalisering og ensomhed. I modsætning til de symbolske hjem, erindringens Somalia og drømmenes London. Om de eftertragtede kvindefællesskaber og ukomplicerede tilhørsforhold reelt findes i de faktiske lokaliteter Somalia og London, er så en anden historie. ${ }^{6}$ Andre kvinder betegner Somalia som et umuligt hjem på grund af restriktive kønsopfattelser, og hvad de betegner som en patriarkalsk kultur. Danmark og det danske velfærdssystem rummer både muligheder og barrierer.

For Omar virker mødet med det danske velfærdssystem truende på hans identitet som somalisk mand. Også her spiller kønnet ind, hvor opbruddet i familie- og kønsrelationer i diaspora sammen med oplevelsen af tabt værdighed og truet maskulinitet bliver til et spørgsmål om kulturkamp. En kulturkamp som samtidig opleves som kønskamp på to planer: I forhold til danske kvinders dominans i velfærdssystemet og i forhold til ændrede magtforhold i familien 
og mellem kønnene. For Omar opleves det tilsyneladende som en form for dobbeltforskydning af kønsrelationerne: kvinderne går frem, mens mændene går tilbage.

Statusfaldet, som Omar, Liza og mange andre gennemlever, viser sig på både den materielle og sociale front. Som ved små og dårlige lejligheder og et liv som bistandsklient, hvor drømmen måske var en universitetsuddannelse. Det er her vigtigt at understrege, at statusfaldet først og fremmest knyttes til livet før borgerkrigen. Før nære familiemedlemmers meningsløse $\mathrm{d} \varnothing \mathrm{d}$, før ødelæggelse af huse og hele byer. Før store dele af familien måske blev spredt ud over kloden. Det diasporiske hjem er dermed forskudt både $\mathrm{i}$ tid og sted. Til erindringer og længsel efter en tid og efter steder uberørt af krig og ødelæggelse. Til mennesker, der måske nu bor andre steder i verden hvis de stadig lever. Med inspiration fra Brah kan vi tale om en 'diasporising af hjem' (Brah 1996, 190). At hjemmet er blevet spredt, mangfoldigt, for den enkelte. Både konkret og billedligt. At drømme og relationer opretholdes hen over landegrænser og kontinenter. Over tid og sted. $\mathrm{Og}$ at kønnet på forskellig vis er med til at definere disse hjem. Det diasporiske hjemme er mere end ét sted. Men det er også mere end et sted.

\section{Noter}

Tak til Mette Fink-Nielsen, referees og Center for Udviklingsforskning.

1. Artiklen tager udgangspunkt i Mette Fink-Nielsens og mit kandidatspeciale om dansk repatrieringspolitik og somaliere i Danmark (Fink-Nielsen \& Kleist 2000). Artiklens empiri er 20 båndede længerevarende interview med $i$ alt 23 somaliere bosat i København og omegn, samt deltagerobservation ved forskellige arrangementer. Samtalerne fandt fortrinsvis sted på dansk, en på engelsk og en med tolk. De blev udført sammen med Mette Fink-Nielsen i efteråret 1999. For en uddybning af metode og teori se Fink-Nielsen \& Kleist (2000). 2. I 1991 udråbte den nordvestlige del af Somalia, den tidligere engelske koloni Britisk Somaliland, sig som selvstændig republik under navnet Somaliland uden at blive internationalt anerkendt. Jeg går ikke her ind i de politiske aspekter af dette i forhold til de diasporiske tilhørsforhold (se Fink-Nielsen, Hansen \& Kleist (forthcoming). For et overblik over Somalias historie se Bradbury (1997) og Samatar (1994).

3. I løbet af de sidste par år er der dog flere universitetsspecialer (færdige eller under færdiggørelse) om somaliere i Danmark. Mediernes fokus på somalierne er analyseret i Fadel, Hervik \& Vestergaard (1999) og Jørgensen \& Bülow (1999). Farah (2000) har skrevet en fremragende bog om den somaliske diaspora med eksempler fra blandt andet Kenya, Italien, London og Sverige.

4. Relanceringen af diasporabegrebet henvises ofte til Safran (1991).

5. Samlet set har somaliske statsborgere i Danmark dog den laveste erhvervsfrekvens blandt etniske minoriteter i Danmark. Lidt over 40\% for mænd, der har boet over fem år i Danmark er i arbejde og ca. $15 \%$ for mænd med ophold under fem år. For kvinder er tallet ca. 18\% og 5\% (Dansk Arbejdsgiverforening 2001, 60-61).

6. Se Farah (2000) og Fink-Nielsen, Hansen \& Kleist (forthcoming) for mere pessimistiske udlægninger af livet i London.

\section{LITTERATUR}

- Affi, Ladan (1997): The Somali Crisis in Canada: The Single Mother Phenomenon, in Hussein M. Omar and Richard Ford (red.): Mending the rips in the sky. Options for Somali Communities in the 21st century. The Red Sea Press Inc, Lawrensville NJ.

- Brah, Avtar (1996): Cartographies of Diaspora. Contesting identities. Routledge, London/New York.

- Braidotti, Rosi (1994): Nomadic Subjects. Embodiment and Sexual Difference in Contemporary Feminist Theory. Columbia University Press, New York.

- Bradbury, Mark (1997): Somaliland Country Report. CIIR, London.

- Clifford, James (1994): Diasporas. In Cultural

Anthropology. Vol 9 (3).

- Cohen, Robin (1997): Global Diasporas. An introduction. UCL Press, London.

- Crisp, J. 1999. Policy challenges of the new diasporas: migrant networks and their impact on asylum flows and regimes. Working Paper no. 7. UNHCR, Geneve.

- Danmark Statistisk (2001): Statistik Årbog.

København. 
- Dansk Arbejdsgiverforening (2001): Integration \& Arbejdsmarked. København.

- Fadel, Ulla Holm, Peter Hervik \& Gitte Vestergaard (1999): De "besværlige" somaliere, in Peter Hervik (red): Den generende forskellighed. Hans Reitzels Forlag, København.

- Farah, Nuruddin (2000): Yesterday, Tomorrow. Voices from the Somali Diaspora. Cassell, London/New York.

. Fink-Nielsen, Mette \& Nauja Kleist (2000): Tilhørsforholdets politikker. En analyse af hvorfor så fä somaliere repatrierer fra Danmark. Kandidatspeciale, Internationale Udviklingsstudier \& Historie, Roskilde Universitets Center.

- Fink-Nielsen, Mette, Peter Hansen \& Nauja Kleist (forthcoming): Roots, Rights and Responsibilities: Place-making and Repatriation among Somalis in Denmark and Somaliland, in Sørensen, Ninna Nyberg, Finn Stepputat \& Nicholas Van Hear (red). Living on the Edge: Conflict, Movement and Everyday Forms of State Formation. Routledge, London/New York.

- George, Rosemary Marangoly (1996): The Politics of Home: Postcolonial relocations and twentiethcentury fiction. Cambridge University Press, Cambridge.

- Geshekter, Charles (1997): The Dead of Somalia in a Historical Perspective, in Hussein M. Omar and Richard Ford (red.): Mending the rips in the sky. Options for Somali Communities in the 21st century. The Red Sea Press Inc, Lawrensville NJ. - Griffiths, David (1997): Somali refugees in Tower Hamlets: clanship and new identities, in New Community. Vol. 23 (1).

- Jørgensen, Rikke Egaa og Vibeke Søderhamn Bülow (1999): Ali og de fyrretyve k(r)oner. En analyse af Ekstra Bladets kampagne "De fremmede", in Peter Hervik (red): Den generende forskellighed. Danske svar på den stigende multikulturalisme. Hans Reitzels forlag, København.

- Lewis, Ian M. (1994): Blood and Bone. The Call of Kinship in Somali Society. The Red Sea Press Inc, Lawrensville NJ.

- Mohamed, Hamdi S. (1997): The Somali Refugee Women's Experience in Kenyan Refugee Camps and Their Plight in Canada, in Hussein M. Omar and Richard Ford (red.): Mending the rips in the sky. Options for Somali Communities in the 21st century. The Red Sea Press Inc, Lawrensville NJ.

- Mørck, Yvonne (1998): Bindestregs-Danskere. Fortellinger om køn, generationer og etnicitet. Forlaget Sociologi, København.
- Peltman, Jan Jindy (1996): Boundary Politics. Women, nationalism and danger, in Maynard \& Purvis (eds) (1996): New Frontiers in Women's Studies. Taylor \& Francis, London.

- Safran, William (1991): Diasporas in modern societies. Myths of homeland and return, in Diaspora, 1 (1).

- Samatar, Said (1994): The Somalia challenge. From Catastrophe to renewal? Lynne Rienner Publishers, Boulder, London.

- Skak, Tine (1998): De er så svære at integrere, in Ann-Belinda Steen Preis (red): Kan vi leve sammen. Integration mellem politik og praksis. Munksgaard, København.

- Udlændingestyrelsen (2000): Udlandingestyrelsens Årsberetning 2000. København.

. UNHCR (2000): The state of the world's refugees 2000. Oxford University Press, Oxford.

- Utteh, Hassan Omar (1997): The Plight of the Somali Refugees in Europe, With Particular reference to Germany (1993), in Hussein M. Omar and Richard Ford (red.): Mending the rips in the sky. Options for Somali Communities in the 21st century. The Red Sea Press Inc, Lawrensville NJ.

- Wargeys. Nyhedsbrev om Somalia 2001, nr. 22. Dansk Flygtningehjælp, København.

- Yuval-Davis, Nira \& Anthias, Floya (1989): Woman, Nation, State. Macmillan, London.

\section{SUMMARY}

The article analyses notions of home, belonging and Somali culture in the narratives of a Somali man and woman in Denmark. The theoretical approach is that of diaspora theory and the concept of politics of belonging. Home and belonging are relational, gendered concepts constructed partly as a response to experiences of everyday racism and marginalization in Denmark. Gender is an important element in the definitions and dreams of home and of the 'Somali way', but the conceptions of ideal gender relations change according to context and perspective.

Nauja Kleist, cand.mag. i Internationale Udviklingsstudier og Historie. 